International Journal of Canadian Studies

Revue internationale d'études canadiennes

INTERNATIONAL JOURNAL OF CANADIAN STUDIES

\title{
Intensive Mothering in British Columbia: Understanding the Impact of an "Investing-in-Children" Framework on Mothering Ideology
}

\section{Kate Butler}

Numéro 42, 2010

URI : https://id.erudit.org/iderudit/1002180ar

DOI : https://doi.org/10.7202/1002180ar

\section{Aller au sommaire du numéro}

\section{Éditeur(s)}

Conseil international d'études canadiennes

\section{ISSN}

1180-3991 (imprimé)

1923-5291 (numérique)

Découvrir la revue

\section{Citer cette note}

Butler, K. (2010). Intensive Mothering in British Columbia: Understanding the Impact of an "Investing-in-Children" Framework on Mothering Ideology. International Journal of Canadian Studies / Revue internationale d'études canadiennes, (42), 243-253. https://doi.org/10.7202/1002180ar

\section{Résumé de l'article}

À notre époque moderne, les cadres stratégiques privilégient l'idée que les enfants doivent être la cible de l'intervention gouvernementale dans les familles. Jane Jenson parle " d'investir dans les enfants ", puisque ce sont eux et non pas leurs parents qui sont, en principe, les principaux bénéficiaires de ces interventions. Ces cadres témoignent d'un virage par rapport à celui de la " responsabilité familiale », qui confie aux parents la responsabilité du bien-être de leurs enfants (Jenson, p. 173). Néanmoins, dans les faits, la stratégie consistant à « investir dans les enfants " n'allège en rien la responsabilité des parents, mais prévoit parallèlement de plus nombreux mécanismes de contrôle sur ces derniers. L'auteur de cette étude se penche sur la relation entre l'idéologie de maternage intensif et la décision "d'investir dans les enfants ". Particulièrement chez les personnes en marge de la société, le nouveau concept de maternité se définit comme une expérience intime et individuelle. L'engagement du gouvernement de la Colombie-Britannique en faveur de "l'investissement dans les enfants » est affirmé dans le document intitulé Strong, Safe and Supported (2008). Cette publication décrit les moyens utilisés pour exercer un contrôle sur les agissements des parents, dans le cadre d'une stratégie faisant appel à une politique gouvernementale pour promouvoir le bien-être des enfants de la Colombie-Britannique. En dépit du fait que la collectivité contribue théoriquement au bien-être des enfants, il va de soi que le contrôle de la responsabilité parentale est tout simplement renforcé.
All Rights Reserved (C Conseil international d'études canadiennes, 2010
Ce document est protégé par la loi sur le droit d'auteur. L’utilisation des services d'Érudit (y compris la reproduction) est assujettie à sa politique d'utilisation que vous pouvez consulter en ligne.

https://apropos.erudit.org/fr/usagers/politique-dutilisation/ 


\title{
Intensive Mothering in British Columbia: Understanding the Impact of an "Investing-in- Children” Framework on Mothering Ideology
}

\begin{abstract}
In our contemporary era, policy frameworks privilege the idea that children should be the target of government intervention in the family. Jane Jenson calls this the "investing-in-children" framework, as children, rather than parents, are supposedly at the forefront of government involvement in family life. This is a shift from an earlier "family responsibility" framework in which parents were held responsible for their child's well-being (Jenson 173). However, the "investing-in-children" framework actually continues to place much responsibility on the shoulders of parents while at the same time creating mechanisms for their further regulation. In this paper, the author explores the relationship between intensive mothering ideology and an "investing-in-children" policy framework. Motherhood (particularly for those at the margins of society) is reconceptualized as a private, individual experience. The BC government's commitment to an "investing-in-children" framework is captured in the 2008 document, Strong, Safe and Supported. This publication captures the ways in which parental regulation is achieved through a strategy of government policy promoting the well-being of BC's children. Although the community is supposedly implicated in the welfare of its children, it is clear that parental responsibility is the main subject of further regulation.
\end{abstract}

\section{Résumé}

À notre époque moderne, les cadres stratégiques privilégient l'idée que les enfants doivent être la cible de l'intervention gouvernementale dans les familles. Jane Jenson parle "d'investir dans les enfants", puisque ce sont eux et non pas leurs parents qui sont, en principe, les principaux bénéficiaires de ces interventions. Ces cadres témoignent d'un virage par rapport à celui de la " responsabilité familiale », qui confie aux parents la responsabilité du bien-être de leurs enfants (Jenson, p. 173). Néanmoins, dans les faits, la stratégie consistant à " investir dans les enfants " n'allège en rien la responsabilité des parents, mais prévoit parallèlement de plus nombreux mécanismes de contrôle sur ces derniers. L'auteur de cette étude se penche sur la relation entre l'idéologie de maternage intensif et la décision " d'investir dans les enfants ». Particulièrement chez les personnes en marge de la société, le nouveau concept de maternité se définit comme une expérience intime et individuelle. L'engagement du gouvernement de la Colombie-Britannique en faveur de "l'investissement dans les enfants" est affirmé dans le docu- 
ment intitulé Strong, Safe and Supported (2008). Cette publication décrit les moyens utilisés pour exercer un contrôle sur les agissements des parents, dans le cadre d'une stratégie faisant appel à une politique gouvernementale pour promouvoir le bien-être des enfants de la Colombie-Britannique. En dépit du fait que la collectivité contribue théoriquement au bien-être des enfants, il va de soi que le contrôle de la responsabilité parentale est tout simplement renforcé.

Ideologies of motherhood refer to culturally agreed upon understandings of what the act of motherhood should look like. These ideologies have pervasive influence over how the mothering discourse is constructed. Current ideologies of mothering privilege the importance of intensive mothering on the part of parental figures. At the same time, we have seen a move towards a policy framework in which children have become the target of government intervention. This shift in our understanding of motherhood has implications for children and parents. Our modern ideology of intensive motherhood works together with "investing-in-children" policy frameworks to legitimize current norms of family responsibility. In this paper, I explore the relationship between an "investing-in-children" framework and intensive mothering. Specifically, I look at the BC's Ministry of Children and Family Development's (MCFD) 2008 publication, Strong, Safe and Supported: A Commitment to B.C.'s Children and Youth. By placing the child as the target of policy intervention, the role of the parent is obscured. Parents are still responsible for the day-to-day care of children, even as government policy frameworks suggest otherwise. The consequences of this are particularly troubling for lone parents with tenuous ties to the workforce.

To explore how the intensive mothering and "investing-in-children" ideologies interact, I first look at how motherhood can be an indirect or direct target of policy frameworks. In our contemporary era, policy frameworks privilege the idea that children should be the target of government intervention in the family. Jane Jenson calls this the "investing-in-children" framework and it provides a useful starting point to look at the shift in notions of parenting, a shift from an earlier "family responsibility" framework (Jenson 173). Secondly, I turn to look at the ideology of intensive mothering. I explore how this guides expectations of parenting as we move away from an individual responsibility policy framework. An ideology of intensive mothering calls for a specific type of parenting, in which mothers must conform to notions of what a "good" parent is. Finally, I examine the regulation of motherhood under an ideology of intensive mothering and "investing-in-children" framework by examining the MCFD's publication, Strong, Safe and Supported. This report sets forth the goals and mission of the ministry and illustrates how intensive mothering ideology is legitimated. 


\section{Impact of Policy Frameworks on Questions of Motherhood}

The understanding of gender as a unique category affected in a particular way by government actions rests upon an assumption that men and women interact differently with state apparatus. Anthias and Yuval-Davis argue,

Women's link to the state is complex. On the one hand, they are acted upon as members of collectivities, institutions or groupings, and as participants in the social forces that give the state its given political projects... On the other hand, they are a special focus of state concerns as a social category with a specific role (particularly human reproduction). (6)

The unique position of women vis-à-vis the state is thus an important aspect of the question of ideologies of motherhood. Through the reproduction of new members of society, women play a central part in the ideological formation of citizens (Anthias and Yuval-Davis 8). With this in mind, motherhood has understandably been affected by various policies historically and cross-culturally.

Changes in how we conceptualize motherhood occur through intersecting social, political, and economic processes. Sometimes, governments have explicit goals in mind when they seek to promote certain family choices or lifestyles. For example, political elites in societies as diverse as Victorian Britain, the Soviet Union, and Nazi Germany encouraged women to embrace particular ideals and notions of motherhood for the "good of the nation" (Zeiger 7; du Toit 157). In the 1917 pamphlet Race Suicide: England's Peril, written by Reverend George W. Clark and published by the Duty and Discipline Movement, this explicit call for women to be mothers emphasizes nationalist rhetoric: "No other service woman can render the State can compensate for her failure in this, the one function God and Nature have assigned to her, and to her alone. Everything else man can do. This is woman's function and her glory. For this, she was sent into the world. Her best years must be spent in the nursery or the nation perishes" (qtd. in Rich 279). Similarly, Joseph Goebbels, Hitler's propaganda minister, spoke about the role he saw for German women under Nazi regime: "The first, best, and most suitable place for the woman is in the family, and her most glorious duty is to give children to her people and nation, children who can continue the line of generations and who guarantee the immortality of the nation...The best place for the woman to serve her people is in her marriage, in the family, in motherhood" (Goebbels 120). These illustrations of how certain ideologies of motherhood are equated with nationalist sentiment are not unique; discursive ties between acts of mothering and glorification of the nation-state are widespread.

However, modern Canadian mothering ideologies are very different from those espoused by political and cultural elites in early-twentieth-century 
Britain or Germany, and such overt calls for particular kinds of mothering are rare. There is little evidence of any kind of mainstream connection between chauvinistic nationalism and mothering ideologies in Canada. Instead, government policies directed at the family have a complicated relationship with individuals affected by these programs. Jane Jenson suggests that we are moving towards a policy framework that is focused on "investing in children." The state is now focusing on the child as the entry point for social programs, rather than the parent. One way that this is evident is through the National Child Benefit (NCB). The government gives out the NCB based on whether or not there are children in a household (Jenson 177-178). The goals of the NCB are twofold: to reduce child poverty and to ensure that parents are better off working than not working. This marks a shift from traditional transfers to families, which based transfer funds on the relationship between the parent and the workforce - those who made less in the workforce had the opportunity to receive more money (Jenson 178). Under an "investingin-children" framework, parents who are not a part of the workforce do not receive additional funds. For lone parent families, this policy shift can be very difficult.

Prior to an "investing-in-children" framework, a "family responsibility" model was in place. This model alludes to public policies that facilitate parental decision-making by allowing a range of options for parents to choose from (Jenson 173). Financial help to families is based on the needs of adults, not the needs of children. In this way, parents are invested with the capacity to make decisions about the well-being of their children. This policy framework assumes that the role of government is to give families choices, even though the available options are often rather limited (Jenson 174). A shift from this model to one in which children are the target of intervention could be seen as a way to rectify individual responsibility of parents to children. However, the "investing-in-children" framework actually continues to place much responsibility on the shoulders of parents, while at the same time creating mechanisms for their further regulation. For example, in the "investing-inchildren" framework, experts are no longer simply social workers or front-line health professionals. We now rely more heavily on experts in early childhood development, population health, and other professionals whose areas of expertise expand our understanding of children-at-risk (Jenson 179).

By focusing on "investing-in-children," then, policies in this framework articulate the notion that the whole community is supposedly responsible for the well-being of children, while actually expanding the ways in which parents can be monitored or held accountable (Jenson 180). On a provincial level, this is evident when we look at the guiding principles of BC's Ministry of Children and Family Development. The principles include an emphasis on the UN Convention on the Rights of the Child, which says that children have the right to "express their own opinions in all matters that affect them and to 
participate fully in family, cultural and social life" (Strong 9). The report goes on to note that parents have primary responsibility, while the government and community have a role to play in supporting and protecting children (Strong 9). In this way, we can see that even though children are supposedly the target of intervention, parents are still held responsible for the day-to-day welfare of the child. Indeed, they are the ones blamed when something goes wrong (Roberts 34).

\section{Intensive Mothering}

Neo-liberal policies at federal, provincial, and municipal levels have played an important role in the perpetuation of "intensive mothering" in Canadian society. This notion, put forward by sociologist Sharon Hays, postulates that North America has embraced "an ideology of intensive mothering (which is) a gendered model that advises mothers to expend a tremendous amount of time, energy, and money in raising their children" (x). Intensive mothering is a cultural contradiction to the logical economic-self model, prevalent in the Western world, in large part due to the neo-liberal turn in society.

Intensive mothering is not the only mothering ideology available: less demanding and intensive ideologies exist. Practices around the appropriate rearing of children are socially constructed, and different eras have embraced different ideologies (Hays 12). However, it is the ideology that modern-day North America has accepted, as evidenced through child-rearing manuals, mommy blogs, parenting magazines, and more. Intensive mothering has become the normalized way of raising children. Mothering becomes childcentred, expert-guided, emotionally absorbing, labour-intensive, and financially expensive (Hays 8). In a Canadian context, sociologist Virginia Caputo looks at expectations around mothering in an educational setting of Ottawa private schools, and finds mothers there to be critical of parents who do not act in accordance with an "intensive mothering" ideology (178). Being a "good mother" means acting in a prescribed way that others recognize as indicative of good parenting. Caputo also points out that expectations inherent to a neo-liberal society about gender and the marketplace play a role in the development of an intensive mothering ideology (173). The gendered nature of intensive mothering may be obscured at times, but it clearly still exists. As Hays argues, "If you are a good mother, you must be an intensive one. The only 'choice' involved is whether you add the role of paid working woman" (131).

This idea of "adding" the role of paid working woman presents a difficulty for poor single mothers. The way current welfare regulations are structured, working (or looking for work) is often a requirement for women with children: no "choice" is involved, and jobs and job conditions are often less than satisfactory. There are some exceptions for women with very small children but, for the most part, work and welfare go hand-in-hand (Jenson 178). 
In addition, there is an added element of regulation facing poor, single mothers in a neo-liberal context. This regulation of mothering has a moral aspect to it, which is not new. Throughout the last century of Canadian history, doctors, politicians, childcare experts, and psychologists have been involved in the regulation of motherhood (Little 13). Early moral reformers attempted to regulate the activities of poor, minority, and Aboriginal mothers through mothers' allowances that restricted and refined the notion of what a good mother was (Valverde 9). Regulation of mothering by particular segments of the Canadian population was infused with a sense of morality and righteousness on the part of reformers. Similarly, modern-day regulation of motherhood is also imbued with moral undertones: moral regulation of those on welfare has continued through programs such as hotlines to report welfare abuse, and the way that potential recipients are screened (Little 165).

In a society where we call upon the family unit to perform support and services that the welfare state previously provided, mothering has been reconceptualized as a private undertaking, antithetical to the outside marketplace (Hays 10-11). At the same time, we expect mothers to behave as rational economic actors in the outside world. Intensive mothering, therefore, has developed as a way for individuals to deal with encroaching neo-liberalism: self-interested gain is widespread, but mothering is portrayed as outside of this framework. The impetus on the parent, and specifically the mother, is to devote her attention to keeping childhood outside of the self-interested economic world. Although intensive mothering began to take shape around the early twentieth century, our current era of individualism has further changed how this ideology works. As mothers are increasingly drawn into the economic world, they are, at the same time, pressured to engage in behaviour that puts the sacred child at the centre of the home. In this way, women are being pulled in different directions: they need to succeed as viable economic actors, and to engage in intensive mothering that is necessarily antithetical to marketplace behaviour.

The experience of mothering has become one in which individual responsibility is key, and there has been an elimination of community support for mothering. Intensive mothering behoves women to act in certain ways if they want to be seen as "good" mothers by both the state and by their peers (Hays 12). In fact, the state has the power to demand evidence of "good mothering" based on intensive mothering ideology, and can cut back recipients' funds as they see fit (Little 168). The state also has the ability to regulate the activities of recipients, to make sure the recipient is acting according to proper mothering ideology. A certain way of life, in this case, around questions of childrearing, is privileged through political activities involving both the nation and the state. As Sue Ruddick argues, 
The state's repositioning of mothers as economic subjects to the point of erasure of their doubled identity as caregivers and the abandonment of the post-Keynesian state of any protection of that status. In this brave new world both men and women had access to entitlements only as economic subjects - as workers. (636)

Simultaneously, the state has the power to demand evidence of so-called "good mothering" based on intensive mothering ideology while cutting back financial and social support if this is missing (Little 165).

An ideology of intensive motherhood has existed in Canada since the beginning of the twentieth century. Early "moral reformers" pressed government officials to adopt legislation requiring single mothers to abide by certain standards in order to raise children properly (Valverde 8). Many Canadian provinces instituted early welfare programs providing aid to mothers who behaved according to middle-class traditions and norms. The rhetoric behind these policies was that single mothers needed supervision in order to "learn" traditional mothering behaviour. The first attempt at social assistance programs in Canada came, in many provinces, in the form of Mothers' Allowances. These small sums of money were given to women who were in need of financial aid because their husbands had died. Little argues, "OMAs most significant trait was the intrusive and intensive moral scrutiny of applicants and recipients" (xviii). In establishing mothers' allowances, nationalist discourse of the time is clear: the mothers' allowance, and subsequent regulation of recipients, were intended to produce "good" Canadian citizens. Family values rhetoric, as espoused by allowance reformers, dictated that deserving mothers stayed home and cared for their children.

Women were apt to lose the money they received if authorities discovered male borders, financial assistance from parents or neighbours, or any other kind of income. Pre-WWII Canada emphasized Victorian notions of separate public and private spheres, and the idea that the "true" place for a woman/mother as being in the home was widespread (Valverde 50). While the ideology was not the same as the current "intensive" strategy, it still required mothers to act in accordance with the middle-class standards of the time (Little 32). Moral regulation, as Alan Hunt argues, is a complicated form of politics that involves both self-regulation and regulation of mothers (3). With this in mind, early moral reformers attempted to teach recipients of mothers' allowances to monitor themselves and each other to ensure that middle-class standards were sustained.

Mothering is increasingly conceived as an intensive experience where the value of the child is priceless, and good mothers are those who spend considerable time, energy, and money ensuring the healthy development of their children. It is considerably more difficult for low-income parents, especially single parents, to engage in this type of intensive, time-consuming 
mothering. This is particularly true with "workfare" policies that require single mothers to work or search for work in order to qualify for assistance.

\section{Strong, Safe and Supported: Intensive Mothering and "Investing-in-Children"}

The BC government's commitment to children and families is captured in the 2008 document Strong, Safe and Supported. In this publication, the Ministry of Children and Family Development lays out the five pillars for their interactions with children. While this document does not specifically put forward new policies, it does illustrate how the programs currently in place meet the goals of the ministry. The five pillars are based on the notion that the child should be the target of government intervention. They include prevention, early intervention, intervention and support, the Aboriginal approach, and quality assurance. The final pillar, quality assurance, is of interest from a government accountability standpoint, but does not reveal anything particularly useful about attitudes towards children or parenting. With this in mind, I examine the first four pillars of Strong, Safe and Supported in an effort to illustrate how an "investing-in-children" policy framework also perpetuates an ideology of intensive mothering.

Strong, Safe and Supported sets out the first principle, prevention, in the following way: "Government will place a primary focus on preventing vulnerability in children and youth by providing strong supports for families, individuals and communities" (Strong 13). Furthermore, the publication states that while parents are ultimately responsible, governments and communities have a role to play in the development of children. The report goes on to detail various programs already in place that illustrate the government's commitment to this pillar. These programs include early child development, childcare, youth empowerment, and cultural activities for children and youth (Strong 14). What is interesting is that these programs claim to be aimed at the child, but parents are still ultimately responsible. Furthermore, the behaviour of parents is the aim of regulation. For example, many prevention programs focus on Fetal Alcohol Syndrome, suggesting that prevention is partly the responsibility of the parent. As one might expect in intensive mothering ideology, individual responsibility is key. The ministry sponsors a parenting program called "Nobody's Perfect," which is carried out locally by different government agencies and other organizations. This program further reinforces the notion that parental responsibility is the focus of the ministry. The government is there to regulate, but individual parents are blamed if something goes wrong.

The second pillar is early intervention, which the publication describes as follows: "Government will provide early intervention services to vulnerable children and youth within their families and communities" (Strong 17). This 
pillar places training for parents as an important part of its mandate. Again, while the target is supposedly children, parents' behaviour is to be regulated. The report goes on to say that the goal is to avoid more intrusive measures of intervention, which is why early intervention is very important (Strong 18). However, what is not discussed is the historical role the government has played in regulating the work of lower class, immigrant, and Aboriginal families. Historically, intrusive measures have often been used in moral regulation in Canada (Little 12).

The third pillar, intervention and support, deals with more serious measures: "Government will provide intervention services and supports based on the assessment of individual needs" (Strong 21). In this section, the report details lowering crime rates among youth in $\mathrm{BC}$, and goes on to discuss various ways that family disputes are settled. Parental behaviour, this time with poor parenting resulting in the removal of children from the home, is regulated through various programs. Counselling, group conferences, and mediation are all options for families that the ministry considers to be in need of intervention. Consistent with intensive mothering ideology, this pillar indicates that parents will face consequences if they fail to act in ways that the government considers appropriate.

Finally, the fourth pillar is particularly related to Aboriginal families and communities: "Aboriginal people will be supported to exercise jurisdiction in delivering child and family services" (Strong 25). However, that support clearly has limits. One of the major planks of this pillar is that the Ministry will work to increase the number of Aboriginal employees with MCFD. In this way, Aboriginal voices can be heard - but only if they play by government rules. There is little in this fourth plank to indicate the government is entrusting Aboriginal communities with greater meaningful participation in the well-being of children and youth. While homecoming ceremonies for Aboriginal children who have lived in foster care have the potential to be important, the root of the issue — who goes to foster care and why — remains untouched.

The $\mathrm{BC}$ government does not explicitly promote intensive mothering as the prevailing ideology for women to follow. However, the ways in which MCFD frames the well-being of children and youth, intensive mothering ideology coincides with an "investing-in-children" framework. Even while governments push policies that target children, at the end of the day, parental accountability is crucial. As Jenson articulates in her discussion of Canada's "investing in children" policy framework, the well-being of children is presented as a partnership between parents, governments, and communities (176). The emphasis is on the child, rather than on the parent in this model. As such, intensive mothering does not diminish in this framework; instead, 
policies hold parents to high standards by calling for the well-being of children across a variety of measures.

\section{Conclusion}

Family policies that target the child, rather than the mother (or father), obscure the actual work and care of the parental figure/s (Jenson 185). Canadian mothers are not cultural "dopes": they interpret, negotiate, and construct their lives through the changes that have occurred in contemporary society. However, intensive mothering encourages women to be "superhuman" in order to oppose the influence of market forces. The government further regulates this ideology by framing policy in a way that targets the child. As we can see in the MCFD's report, Strong, Safe and Supported, every child in $\mathrm{BC}$ is supposed to have access to programs that will promote well-being. To regulate this well-being of children, the $\mathrm{BC}$ government puts forward a number of programs targeting mothers. Moving away from a family responsibility model might look as though the community is taking a larger role in raising children, but in reality, it just opens the door for further regulatory measures.

\section{Works Cited}

Anthias, Floya, and Nira Yuval-Davis. Woman-Nation-State. London: MacMillan, 1989.

Caputo, Virginia. “'She's From a 'Good Family': Performing Childhood and Motherhood in a Canadian Private School Setting." Childhood 14.2 (2007): 173-192.

du Toit, Marijke. "The Domesticity of Afrikaner Nationalism: Volksmoeders and the ACW 1904-1929." Journal of Southern African Studies 29.1 (2003): 155-177.

Goebbels, Joseph. "Deutsches Frauentum." Signale der neuen Zeit. 25 ausgewählte Reden von Dr. Joseph Goebbels. Munich: Zentralverlag der NSDAP, 1934: 118-126. 20 Nov. 2008 http://www.calvin.edu/academic/cas/gpa/goeb55.htm

Hays, Sharon. The Cultural Contradictions of Motherhood. New Haven: Yale University Press, 1996.

Hunt, Alan. Governing Morals: A Social History of Moral Regulation. Cambridge: Cambridge University Press, 1999.

Jenson, Jane. "Changing the Paradigm: Family Responsibility or Investing in Children." Canadian Journal of Sociology 29.2 (2004): 169-192.

Little, Margaret. "No Car, No Radio, No Liquor Permit": The Moral Regulation of Single Mothers in Ontario, 1920-1997. Toronto: Oxford University Press, 1998.

Rich, Adrienne. Of Woman Born: Motherhood as Experience and Institution. New York: W.W. Norton, 1976.

Roberts, Dorothy. "Mothers Who Fail to Protect Their Children: Accounting for Private and Public Responsibility." Mother Troubles: Rethinking Contemporary Maternal Dilemmas Eds. J. Hanigsberg and S. Ruddick. Boston: Beacon Press, 1999: 31-49.

Ruddick, Sue. "At the Horizons of the Subject: Neo-liberalism, Neo-Conservatism and the Rights of the Child. Part Two: Parent, Caregiver, State." Gender, Place and Culture 14.6 (2007): 627-640. 
Strong, Safe and Supported: A Commitment to B.C. 's Children and Youth. Ministry of Children and Family Development, 2008.

Valverde, Mariana. The Age of Light, Soap, and Water: Moral Reform in English Canada 1885-1925. Toronto: McClelland \& Stewart, 1991.

Zeiger, Susan, "She Didn't Raise Her Boy to be a Slacker: Motherhood, Conscription, and the Culture of the First World War." Feminist Studies 22 (1996): 6-39. 